KONSTRUKTIVISME, Vol. 10, No. 2, Juli 2018

p-ISSN: 1979-9438; e-ISSN: 2442-2355

FKIP Universitas Islam Balitar, Blitar

Http://konstruktivisme.unisbablitar.ejournal.web.id; Email: konunisba@gmail.com

\title{
KETERAMPILAN BERPIKIR KRITIS MAHASISWA MATA KULIAH EKOLOGI TUMBUHAN MENGGUNAKAN MODEL PEMBELAJARAN INKUIRI
}

\author{
Ayatusa'adah \\ Prodi Tadris Biologi FTIK Institut Agama Islam Negeri Palangka Raya \\ Jl. G. Obos Komplek Islamic Centre \\ E-mail: ayatussaadah@iain-palangkaraya.ac.id
}

\section{ABSTRAK:}

Tujuan penelitian ini yaitu untuk mendeskripsikan keterampilan berpikir kritis mahasiswa pada mata kuliah ekologi tumbuhan melalui pembelajaran inkuiri. Jenis penelitian ini adalah penelitian deskriptif kuantitatif dengan desain penelitian one group pretest- posttest design (desain kelompok tunggal dengan pretes-posttes). Teknik pengumpulan data menggunakan pretest dan posttest untuk mengukur keterampilan berpikir kritis mahasiswa dalam memahami selama pembelajaran. Data penelitian kemampuan berpikir kritis dari pretes dan posttes dianalisis dengan menghitung nilai $N$-gain. Hasil $N$-gain menunjukkan penggunaan model inkuiri dapat meningkatkan keterampilan berpikir kritis mahasiswa. Data posttes mahasiswa dianalisis secara deskriptif untuk menggambarkan kemampuan berpikir kritis mahasiswa melalui pembelajaran inkuiri. Rata-rata skor tertinggi pada indikator pertama, yaitu memfokuskan pertanyaan dengan skor 73,64 yang terkategori sedang. Rata-rata skor terendah terdapat pada dua indikator, yaitu pada indikator bertanya dan menjawab pertanyaan dan indikator mempertimbangkan sumber apakah dapat dipercaya atau tidak. Kedua indikor tersebut sama-sama mendapatkan skor 70 dengan kriteria sedang. Rata-rata semua indikaor keterampilan berpikir kritis mahasiswa mendapat skor 71,27 dengan kriteria sedang. Pembelajaran inkuiri dapat meningkatkan keterampilan berpikir kritis mahasiswa dengan rata-rata kriteria sedang

Kata Kunci: Inkuiri, berpikir kritis

\section{ABSTRACT:}

The purpose of this study is to describe students' critical thinking skills in Plant Ecology courses through inquiry learning. This type of research is a quantitative descriptive research with one group pretest-posttest research design (single group design with pretest-posttest). Data 
collection techniques used pretest and posttest to measure students' critical thinking skills in understanding during learning. Research data on critical thinking skills from the pretest and posttest were analyzed by calculating the $\mathrm{N}$-gain value. $\mathrm{N}$-gain results indicate that the use of inquiry models can improve students' critical thinking skills. Students' posttest data were analyzed descriptively to describe students' critical thinking skills through inquiry learning. The highest average score on the first indicator, which is focusing on questions,gotscore of 73.64, in the criteria of sufficient. The lowest average score is found in two indicators, namely the indicator asking and answering questions and the indicator considering whether the source is reliable or not. Both indicators got a score of 70 in the criteria of sufficient. On average all indicators of critical thinking skills of students got a score of 71.27 in the criteria of sufficient. The conclusion is that the Inquiry learning is able to improve students' critical thinking skills in the medium criteria.

Keywords: inquiry, critical thinking

\section{PENDAHULUAN}

Globalisasi berefek pada dituntutnya mahasiswa memiliki keterampilan untuk menjawab tantangan abad 21. Dalam Chaeruman (2010) Perserikatan Bangsa Bangsa (PBB) menyebutkan masyarakat era global saat ini memiliki ciri berpengetahuan (knowledge-based scoeity) dengan berbagai keterampilan, yaitu keterampilan menguasai teknologi informasi dan komunikasi (information \& communication technology literacy skill), keterampilan berpikir kritis (critical thinking skill), keterampilan memecahkan masalah (problem solving skil), keterampilan berkomunikasi efektif (effective communication skill) dan keterampilan berkolaborasi (collaborate skill). Masyarakat diharapkan dapat menjawab tantantangan abad 21 dengan memiliki kemampuan untuk dapat memecahkan masalah-masalah dalam kehidupan yang dihadapinya melalui keterampilan berpikir kritis.

Keterampilan berpikir kritis merupakan salah satu kriteria capaian dalam pembelajaran yang dinyatakan Dirjen Dikti (2014) bahwa pembelajaran pada jenjang pendidikan tinggi (sarjana) memiliki kriteria kemampuan berpikir kritis, logis, inovatif, bermutu dan terukur. Keterampilan berpikir kritis menurut Paul \& Elder (2006) merupakan cara berpikir bagi seseorang untuk meningkatkan kualitas melalui hasil pemikiran menggunakan teknik sistematis dan menghasilkan daya pikir intelektual. Berpikir kritis diharapkan dapat memacu mahasiswa memecahkan permasalahan yang diajukan dalam proses pembelajaran. 
Ekologi tumbuhan merupakan salah satu mata kuliah yang ditempuh mahasiswa pendidikan biologi sebagai calon guru biologi. Ekologi tumbuhan menuntut mahasiswa calon guru biologi untuk mampu menganalisis gejalagejala alam yang berkaitan dengan dunia tumbuhan. Standar Kualifikasi Akademik dan Kompetensi Guru Mata Pelajaran Biologi dalam Permen Diknas No.16 tahun 2007 di antaranya menyebutkan guru harus: (1) Memahami proses berpikir dalam mempelajari proses dan gejala alam, (2) Menjelaskan penerapan hukum-hukum biologi dalam teknologi yang terkait dengan biologi terutama yang dapat ditemukan dalam kehidupan sehari-hari, (3) Bernalar secara kualitatif maupun kuantitatif tentang proses dan hukum biologi. Menganalisis standar kualifikasi dan kompetensi tersebut, keterampilan berpikir kritis mahasiswa merupakan kualifikasi dan kompetensi akademik yang sangat penting dan harus dikuasai oleh guru, sehingga perlu adanya peningkatan keterampilan berpikir yang maksimal kepada calon guru biologi melalui pengembangan keterampilan berpikir kritis mahasiswa.

Pembelajaran yang dapat membantu mengembangkan keterampilan berpikir kritis mahasiswa yaitu melalui pembelajaran inkuiri. Falahudin (2016) menyatakan pembelajaran inkuiri dapat memberikan kesempatan bagi peserta didik untuk menemukan sendiri pengetahuannya serta berperan aktif dalam pembelajaran sehingga diharapkan mampu memahami konsep dengan baik dan mengembangkan kemampuan berpikir kritis. Hal ini sejalan dengan pendapat Damayanti (2013) yang menyatakan pembelajaran inkuiri adalah rangkaian kegiatan pembelajaran yang menekankan pada proses berpikir secara kritis dan analitis untuk mencari dan menemukan jawaban dari suatu masalah yang dipertanyakan. Kegiatan pembelajaran yang menekankan mahasiswa pada proses berpikir kritis dan analisis diharapkan dapat menumbuhkan keterampilan berpikir kritis mahasiswa.

Garrison dan Archer dalam Ibrahim (2007) menyatakan inkuiri dan berpikir kritis merupakan dua hal yang sangat berkaitan satu sama lain. Inkuiri sebagai model pembelajaran dan berpikir kritis sebagai proses belajar untuk membangun makna dan mengkonfirmasikan pemahaman mengenai sesuatu materi dalam proses pembelajaran (Fitriani, 2017). Tahapan-tahapan pembelajaran dalam inkuiri dapat membantu mahasiswa untuk aktif dalam memecahkan masalah dan mamacu mahasiswa untuk berpikir. Tahapan pembelajaran inkuiri menurut Trianto (2011) yaitu 1) menyajikan pertanyaan atau masalah, 2) membuathipotesis, 3) Merancang percobaan, 4) melakukan percobaan untuk memperoleh informasi, 5)mengumpulkan data dan mengolah data, dan 6) membuat kesimpulan.

Berdasarkan uraian di atas, keterampilan berpikir kritis mahasiswa sangat penting untuk dikembangkan melalui pembelajaran inkuiri sebagai upaya dalam menyiapkan mahasiswa yang berilmu, cakap, kritis, kreatif dan inovatif sesuai tuntutan pendidikan perguruan tinggi yang mampu bersaing 
Ayatusa'adah. 2018. Keterampilan Berpikir Kritis Mahasiswa Mata Kuliah Ekologi Tumbuhan Menggunakan Model Pembelajaran Inkuiri.

Konstruktivisme, 10 (2): 218-230

untuk menjawab tantangan abad 21. Berpikir kritis juga menjadi dasar dalam membentuk pribadi mahasiswa yang kreatif dan inovatif (Liliasari, 2009). Tujuan penelitian ini yaitu untuk mendeskripsikan keterampilan berpikir kritis mahasiswa pada mata kuliah ekologi tumbuhan melalui pembelajaran inkuiri.

\section{METODE PENELITIAN Jenis Penelitian}

Jenis penelitian ini adalah penelitian deskriptif kuantitatif dengan desain penelitian one group pretest- posttest design (desain kelompok tunggal dengan pretes-posttes). Desain penelitian dikembangkan dengan menggunakan satu kelas eksperimen.

\section{Waktu dan Tempat Penelitian}

Penelitian ini dilakukan di IAIN Palangka Raya pada semester genap tahun ajaran 2017/2018.

\section{Subyek Penelitian}

Subjek penelitian ini adalah mahasiswa Tadris Biologi IAIN Palangka Raya semeseter VI tahun ajaran 2017/2018.

\section{Prosedur Penelitian}

Teknik pengumpulan data dilakukan dengan memberikan pretest di awal pembelajaran, kemudian melakukan proses pembelajaran dengan menggunakan model pembelajaran inkuiri selama dua kali pertemuan. Pada akhir pembelajaran diberikan posttest untuk mengukur keterampilan berpikir kritis mahasiswa dalam memahami selama pembelajaran. Metode pengumpulan data dilakukan dengan metode dokumentasi dan tes. Instrumen yang digunakan dalam penelitian ini meliputi lembar tes soal essay keterampilan berpikir kritis digunakan untuk mengetahui peningkatan keterampilan berpikir kritis.

\section{Teknik Analisis Data}

Data penelitian kemampuan berpikir kritis dari pretes dan posttes dianalisis dengan menghitung nilai normalitas gain ( $N$-gain). Kriteria gain ternormalisasi dari Archambault (2008) yaitu $\mathrm{N}$-gain $>0,70$ (tinggi), $0,30 \leq N$-gain $\leq 0,70$ (sedang) dan $\mathrm{N}$-gain < 0,30 (rendah). Data posttes mahasiswa dianalisis secara deskriptif untuk menggambarkan kemampuan berpikir kritis mahasiswa melalui pembelajaran inkuiri. Kriteria keterampilan berpikir kritis mahasiswa dari Arikunto (2007) yaitu, 75\% - 100\% (Tinggi), 51\% - 74\% (Sedang), 25\% $50 \%$ (Rendah) dan $0-24 \%$ (Sangat Rendah).

\section{HASIL}

Kegiatan pembelajaran menggunakan model pembelajaran inkuiri pada matakuliah ekologi tumbuhan mendapatkan data peningkatan keterampilan berpikir kritis mahasiswa. Sebelum melaksanakan kegiatan pembelajaran dilakukan pretest untuk mengukur kemampuan awal mahasiswa, selanjutnya 
Ayatusa'adah. 2018. Keterampilan Berpikir Kritis Mahasiswa Mata Kuliah Ekologi Tumbuhan Menggunakan Model Pembelajaran Inkuiri.

Konstruktivisme, 10 (2): 218-230

dilaksanakan kegiatan pembelajaran pada matakuliah ekologi tumbuhan materi produktivitas dengan model pembelajaran inkuiri. Mahasaiswa melakukan diskusi kelompok berbantu video sebagai bahan diskusi untuk memudahkan kegiatan menemukan sendiri pengetahuan mereka. Setelah proses pembelajaran selesai dilakukan posttes untuk mengukur kemampuan mahasiswa. Baik kemampuan kognitif maupun keterampilan berpikir kritis mahasiswa. Hasil pretest dan posttes kemudian dihitung selisihnya untuk mencari nilai $\mathrm{N}$-gain, hasil rata-rata pretest, posttest dan nilai $\mathrm{N}$-gain 21 orang mahasiswa seperti disajikan pada Tabel 1.

Tabel 1. Hasil Rata-rata N-Gain Mahasiswa

\begin{tabular}{lcccc}
\hline & Pretest & Posttest & N-Gain & Kriteria \\
\hline $\begin{array}{l}\text { Nilai Rata-rata } \\
21 \text { orang } \\
\text { Mahasiswa }\end{array}$ & 36,19 & 73,23 & 0,58 & Sedang \\
\hline Kenana & & & & \\
\hline
\end{tabular}

Keterangan:

$N$-gain $>0,70$ (tinggi), $0,30 \leq N$-gain $\leq 0,70$ (sedang) dan $N$-gain $<0,30$ (rendah) (Archambault, 2008).

Nilai rata-rata 21 orang mahasiswa pada kegiatan pembelajaran matakuliah ekologi tumbuhan materi poduktivitas menggunakan model pembelajaran inkuiri memperoleh nilai $\mathrm{N}$-gain 0,58 yang terkategori sedang. Kegiatan pembelajaran menggunakan model pembelajaran inkuiri membantu mengarahkan mahasiswa untuk aktif selama proses pembelajaran dan melatih mahasiswa untuk dapat berpikir kritis. Setelah proses pembelajaran dilakukan posttest, dimana soal posttest tersebut juga menguji keterampilan berpikir kritis mahasiswa. Beberapa keterampilan yang dimunculkan dalam soal yaitu: 1. Memfokuskan Pertanyaan, 2. Menganalisis Argumen 3. Bertanya dan Menjawab Pertanyaan, 4. Mempertimbangkan Sumber Apakah Dapat Dipercaya atau Tidak, 5. Membuat dan Menentukan Hasil Pertimbangan. Hasil rata-rata keterampilan berpikir kritis mahasiswa disajikan pada Tebel 2.

Tabel 2. Rata-rata Keterampilan Berpikir Kritis Mahasiswa

\begin{tabular}{lcc}
\hline \multicolumn{1}{c}{ Indikator } & Skor & Kriteria \\
\hline Memfokuskan Pertanyaan & 73,64 & Sedang \\
Menganalisis Argumen & 72,27 & Sedang \\
Bertanya dan Menjawab Pertanyaan & 70 & Sedang \\
Mempertimbangkan Sumber Apakah Dapat Dipercaya atau & & Sedang \\
Tidak & 70 & \\
Membuat dan Menentukan Hasil Pertimbangan & 70,45 & Sedang \\
\hline Rata-rata & $\mathbf{7 1 , 2 7}$ & Sedang \\
\hline Keterangan: & &
\end{tabular}


Ayatusa'adah. 2018. Keterampilan Berpikir Kritis Mahasiswa Mata Kuliah Ekologi Tumbuhan Menggunakan Model Pembelajaran Inkuiri.

Konstruktivisme, 10 (2): 218-230

$75 \%-100 \%$ (Tinggi), 51\% - 74\% (Sedang), 25\% - 50\% (Rendah) dan $0-24 \%$ (Sangat Rendah) (Arikunto, 2007).

Keterampilan berpikir kritis mahasiswa mendapatkan skor rata-rata yang berbeda tiap indikatornya. Rata-rata skor tertinggi pada indikator pertama, yaitu memfokuskan pertanyaan dengan skor 73,64 yang terkategori sedang. Rata-rata skor terendah terdapat pada dua indikator, yaitu pada indikator bertanya dan menjawab pertanyaan dan indikator mempertimbangkan sumber apakah dapat dipercaya atau tidak. Kedua indikor tersebut sama-sama mendapatkan skor 70 dengan kriteria sedang. Rata-rata semua indikaor keterampilan berpikir kritis mahasiswa mendapat skor 71,27 dengan kriteria sedang.

\section{BAHASAN}

Kegiatan pembelajaran mata kuliah ekologi tumbuhan menggunakan model pembelajaran inkuiri berpengaruh terhadap keterampilan berpikir kritis mahasiswa IAIN Palangka Raya. Hasil ini didukng dengan adanya peningkatan keterampilan berpikir kritis mahasiswa dengan rata-rata gain sebesar 0,58 yang terkategori sedang. Peningkatan keterampilan berpikir mahasiswa terlihat dari jawaban pretest dan posttes mahasiswa setelah mengikuti pembelajaran dengan model pembelajaran inkuiri. Hasil pretest dan posttes dapat dilihat seperti pada Diagram 1.

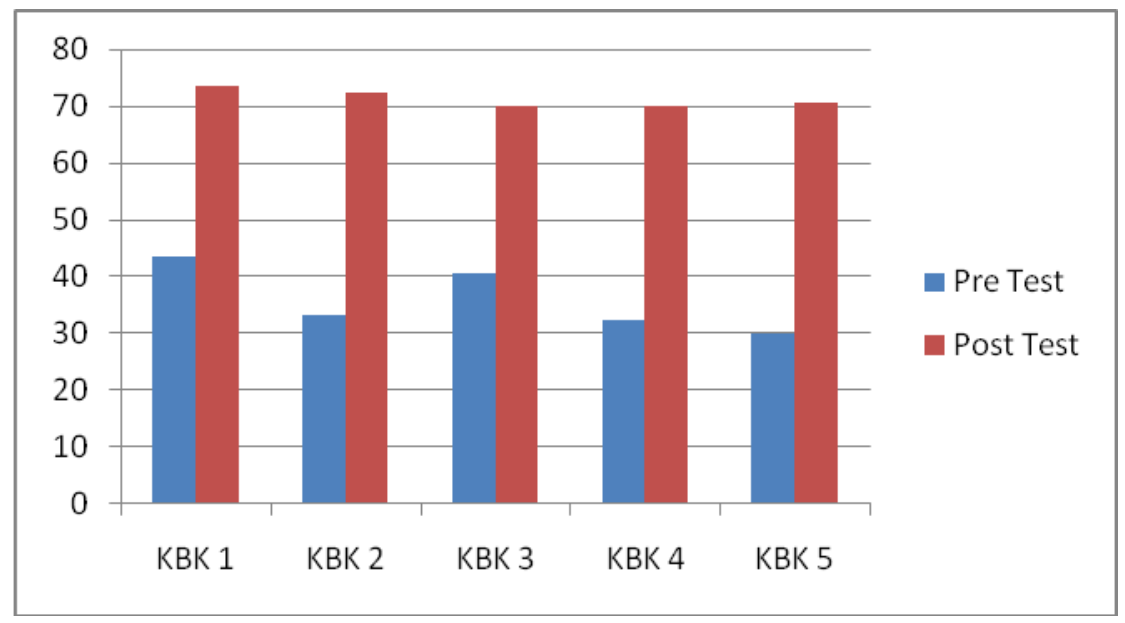

Diagram 1. Hasil Pretest dan Posttest mahasiswa

Kegiatan pembelajaran dengan model inkuiri terbimbing meningkatkan keterampilan berpikir kritis mahasiswa. Model pembelajaran inkuiri yang menekankan pada proses menemukan sendiri pengetahuan menuntun mahasiswa untuk berpikir kritis dan analitis dalam menemukan pengetahuan 
Ayatusa'adah. 2018. Keterampilan Berpikir Kritis Mahasiswa Mata Kuliah Ekologi Tumbuhan Menggunakan Model Pembelajaran Inkuiri.

Konstruktivisme, 10 (2): 218-230

sehingga mengembangkan keterampilan berpikir kritis mahasiswa. Hal ini sejalan dengan penelitian yang dilakukan Ariyati (2015), Falahuddin (2016), dan Syafitri (2016).

Pembelajaran pada matakuliah ekologi tumbuhan materi produktivitas diajarkan dengan model inkuiri untuk mengukur keterampilan berpikir tingkat tinggi mahasiswa. Sebelum kegiatan pembelajaran dilaksanakan dilakukan perencanaan pembelajaran. Kegiatan perencanaan dalam pembelajaran membantu pengajar untuk mempersiapkan proses pembelajaran yang aktif. Menurut Ayatusa'adah (2016) pembelajaran yang aktif adalah pembelajaran yang berfokus pada peserta didik. Hal ini sejalan dengan model inkuiri yang digunakan. Model inkuiri yang digunakan berfokus pada mahasiswa yang akhirnya mengaktifkan mahasiswa selama proses pembelajaran.

Pembelajaran dilaksanakan sesuai dengan tahapan model inkuiri dan melibatkan mahasiswa secara aktif. Proses pembelajaran berbantu video sebagai media pembelajaran untuk memudahkan mahasiswa dalam menemukan sendiri pengetahuannya. Keaktifan mahasiswa terlihat dari terlibatnya mahasiswa dalam mengamati video, membuat pertanyaan berdasarkan video yang diamati, membentuk hipotesis, merencanakan dan melakukan penyelidikan untuk memecahkan masalah dengan bantuan video terkait produktivitas tumbuhan, menginterpretasikan hasil, membuat kesimpulan, generalisasi dan asumsi. Hal ini sejalan dengan sasaran utama pembelajaran inkuiri menurut Uno (1990) yaitu adanya keterlibatan mahasiswa secara maksimal dalam proses belajar mengajar, keberlangsungan kegiatan secara logis dan sistematis pada tujuan pembelajaran, serta mengembangkan sikap percaya diri pada mahasiswa tentang apa yang ditemukan dalam proses inkuiri.

Pembelajaran inkuiri yang dilaksanakan sesuai dengan tahapan inkuiri yang dinyatakan Sagala (2006) yaitu: (1) perumusan masalah yang dipecahkan siswa, (2) menetapkan jawaban sementara (hipotesis), (3) mahasiswa mencari informasi, data fakta yang diperlukan untuk menjawab permasalahan, (4) menarik kesimpulan jawaban atau generalisasi, dan (5) mengaplikasikan kesimpulan atau generalisasi dalam situasi baru. Pembelajaran dilaksanakan berbatu video terkait proses produktivitas tumbuhan saat tahapan mengamati dan mencari informasi, data dan fakta yang diperlukan untuk mejawab permasalahan.

Media video yag digunakan dalam proses pembelajaran inkuiri merupakan salah satu bentuk variasi sumber untuk membantu mahasiswa mengevaluasi, menganalisis dan menginterpretasi data secara kritis. Hal ini juga ditegaskan oleh Ibrahim (2007) yang menyatakan secara umum inkuiri merupakan proses yang bervariasi dan meliputi kegiatan-kegiatan mengobservasi, merumuskan pertanyaan yang relevan, mengevaluasi buku dan sumber informasi lain secara kritis, merencanakan penyelidikan atau 
Ayatusa'adah. 2018. Keterampilan Berpikir Kritis Mahasiswa Mata Kuliah Ekologi Tumbuhan Menggunakan Model Pembelajaran Inkuiri.

Konstruktivisme, 10 (2): 218-230

investigasi, mereview apa yang telah diketahui, melaksanakan percobaan atau eksperimen dengan menggunakan alat untuk memperoleh data, menganalisis dan menginterpretasi data, serta membuat prediksi dan mengkomunikasikan hasilnya.

Proses pembelajaran inkuiri yang dilaksanakan juga sudah sesuai dengan langkah-langkah yang dikemukakan Sanjaya (2006) yaitu (1) orientasi, langkah orientasi adalah langkah untuk membina suasana atau iklim pembelajaran yang responsif sehingga dapat merangsang dan mengajak untuk berpikir memecahkan masalah (2) merumuskan masalah, merumuskan masalah merupakan langkah membawa siswa pada suatu persoalan yang mengandung teka teki, (3) mengajukan hipotesis, hipotesis adalah jawaban sementara dari suatu permasalahan yang sedang di kaji. Sebagai jawaban sementara, hipotesis perlu di uji kebenarannya (4) mengumpulkan data, mengumpulkan data adalah aktifitas menjaring informasi yang dibutuhkan untuk menguji hipotesis yang diajukan (5) menguji hipotesis, menguji hipotesis adalah proses menentukan jawaban yang dianggap diterima sesuai dengan data atau informasi yang diperoleh berdasarkan pengumpulan data (6) merumuskan kesimpulan, merumuskan kesimpulan adalah proses mendeskripsikan temuan yang diperoleh berdasarkan hasil pengujian hipotesis.

Tahapan dalam pembelajaran dengan model inkuiri melatih mahasiswa untuk berpikir kritis. Zubaidah 2010 mengartikan berpikir kritis sebagai proses dan kemampuan yang digunakan untuk memahami konsep, menerapkan, mensintesis dan mengevaluasi informasi yang diperoleh atau informasi yang dihasilkan. Informasi yang diperoleh tidak semua dapat dijadikan pengetahuan yang diyakini kebenarannya untuk dijadikan panduan dalam tindakan, dan tidak selalu informasi yang dihasilkan merupakan informasi yang benar.

Berpikir kritis merupakan salah satu bentuk keterampilan berpikir tingkat tinggi. Angelo (1995) dalam Zubaidah (2010) mengidentifikasi lima perilaku yang sistematis dalam berpikir kritis yaitu (1) Keterampilan Menganalisis, (2) Keterampilan Mensintesis, (3) Keterampilan Mengenal dan Memecahkan Masalah, (4) Keterampilan Menyimpulkan dan (5) Keterampilan Mengevaluasi atau Menilai. Kelima perilaku tersebut dapat dijadikan sebagai indikator keterampilan berpikir kritis.

Berpikir kritis dapat dikenali dari beberapa indikator yang menjadi karateristik berpikir kritis. Ada 13 indikator karakter berpikir kritis yang dikembangkan Ennis (1985) yaitu (1) Mencari pertanyaan jelas dari teori dan pertanyaan, (2) Mencari alasan, (3) Mencoba menjadi yang teraktual, (4) Menggunakan sumber-sumber yang dapat dipercaya dan menyatakannya, (5) Menjelaskan keseluruhan situasi, (6) Mencoba tetap relevan dengan ide utama, (7) Menjaga ide dasar dan orisinil di dalam pikiran, (8) Mencari alternatif, (9) Berpikiran terbuka, (10) Mengambil posisi (dan mengubah posisi) 
Ayatusa'adah. 2018. Keterampilan Berpikir Kritis Mahasiswa Mata Kuliah Ekologi Tumbuhan Menggunakan Model Pembelajaran Inkuiri.

Konstruktivisme, 10 (2): 218-230

ketika bukti-bukti dan alasan-alasan memungkinkan untuk melakukannya, (11) Mencari dokumen-dokumen dengan penuh ketelitian, (12) Sepakat dalam suatu cara yang teratur dengan bagian-bagian dari keseluruhan kompleks, (13) Peka terhadap perasaan, pengetahuan, dan kecerdasan orang lain. Indikator-indikator berpikir kritis diatas diringkas menjadi lima kelompok besar. Kelima kelompok ini dapat dipraktekkan secara bersamaan maupun terpisah-pisah menjadi beberapa indikator saja. Kelima indikator tersebut dijelaskan Ennis (1985) menjadi (1) Memberikan penjelasan sederhana, yang berisi: memfokuskan pertanyaan, menganalisis pertanyaan dan bertanya, serta menjawab pertanyaan tentang suatu penjelasan atau pernyataan, (2) Membangun keterampilan dasar, yang terdiri atas mempertimbangkan apakah sumber dapat dipercaya atau tidak dan mengamati serta mempertimbangkan suatu laporan hasil observasi, (3) Menyimpulkan, yang terdiri atas kegiatan mendeduksi atau mempertimbangkan hasil deduksi, meninduksi atau mempertimbangkan hasil induksi, dan membuat serta menentukan nilai pertimbangan (4) memberikan penjelasan lanjut, yang terdiri atas mengidentifikasi istilah-istilah dan definisi pertimbangan dan juga dimensi, serta mengidentifikasi asumsi (5) Mengatur strategi dan teknik, yang terdiri atas menentukan tindakan dan berinteraksi dengan orang lain.

Indikator keterampilan berpiki kritis yang dikembangkan dalam penelitian ini diantaranya adalah 1. memfokuskan pertanyaan, 2. menganalisis argumen 3 . bertanya dan menjawab pertanyaan, 4. mempertimbangkan sumber apakah dapat dipercaya atau tidak, 5. membuat dan menentukan hasil pertimbangan. Kelima indikator diatas dikembangkan dalam soal tes untuk menguji seberapa besar keterampilan berpikir kritis mahasiswa setelah diberikan pembelajaran dengan model inkuiri.

Data keterampilan berpikir kritis mahasiswa dari hasil pembelajaran ekologi tumbuhan menggunakan model pembelajaran inkuiri diperoleh setelah dilakukan posttes. Hasil posttes menunjukkan data seperti pada Diagram 2. Hasil keterampilan berpikir kritis mahasiswa. 
Ayatusa'adah. 2018. Keterampilan Berpikir Kritis Mahasiswa Mata Kuliah Ekologi Tumbuhan Menggunakan Model Pembelajaran Inkuiri. Konstruktivisme, 10 (2): 218-230

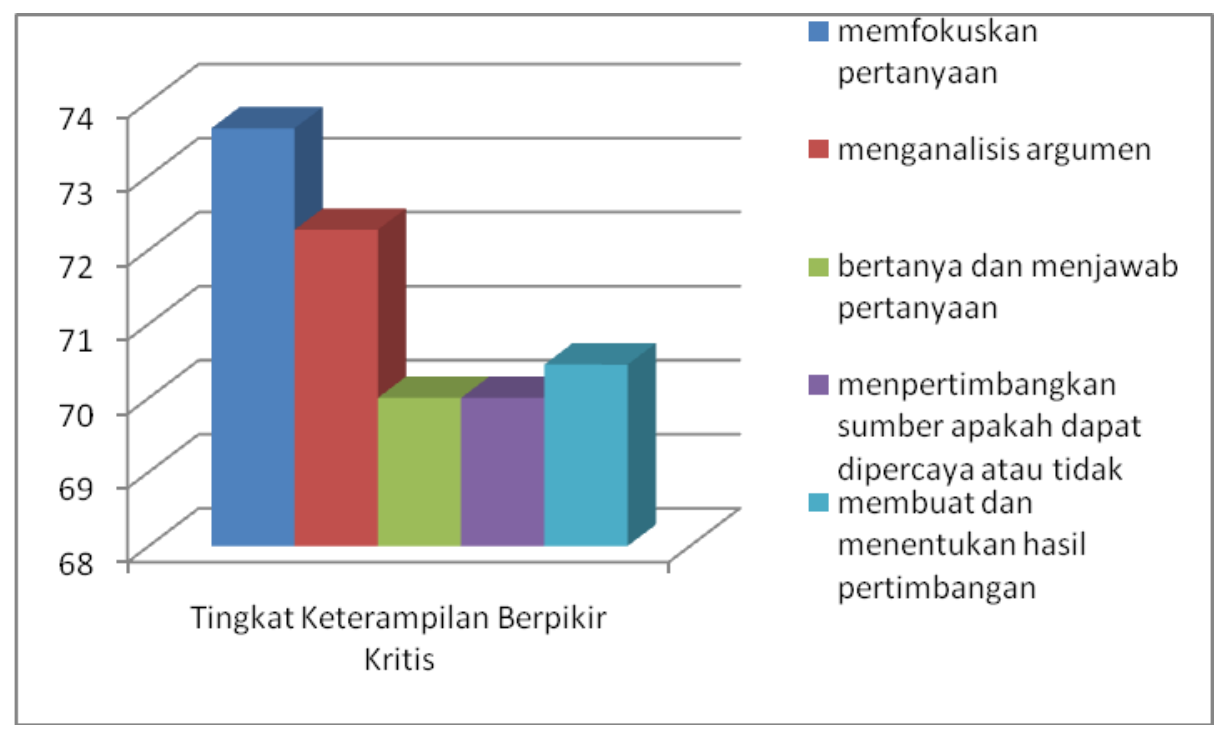

Diagram 2. Hasil Keterampilan Berpikir Kritis

Pembelajaran dengan model inkuiri dapat meningkatkan keterampilan berpikir kritis mahasiswa. Seperti pada Diagram 2 yang menunjukkan keterampilan berpikir kritis mahasiswa sudah terkategori sedang dengan skor minimal 70. Hal ini sejalan dengan penelitian yang pernah dilakukan Ariyati (2015), Falahuddin (2016), dan Syafitri (2016) yang menyatakan keterampilan berpikir kritis peserta didik dapat ditingkatkan melalui pembelajaran inkuiri.

Kemampuan mahasiswa dalam memfokuskan pertanyaan menjadi kemampuan dengan skor tertinggi dari kelima kemapuan yang dinilai. Hal ini dikarenakan dalam model inkuiri terdapat tahapan merumuskan pertanyaan. Adanya tahapan tersebut melatih mahasiswa untuk terbiasa merumuskan suatu permasalahan dan memudahkannya dalam memfokuskan pertanyaan. Meskipun mendapat nilai tertinggi kemampuan mahasiswa Tadris Biologi IAIN palangkaraya dalam memfokuskan pertanyaan masih tergolong sedang dengan skor 73,64.

Kemampuan mahasiswa dalam menganalisis argumen mendapat rengking kedua tertinggi dari kelima kemampuan yang dinilai. Kemampuan mahasiswa dalam menganalisis argumen pada materi produktivitas tergolong sedang dengan skor 72,27 .

Kemampuan mahasiswa dalam membuat dan menentukan hasil pertimbangan mendapat rengking ketiga tertinggi dari kelima kemampuan yang dinilai. Kemampuan mahasiswa dalam membuat dan menentukan hasil pertimbangan pada materi produktivitas tergolong sedang dengan skor 70,45.

Kemampuan mahasiswa dalam bertanya dan menjawab pertanyaan mendapat rengking terendah dari kelima kemampuan yang dinilai. 
Ayatusa'adah. 2018. Keterampilan Berpikir Kritis Mahasiswa Mata Kuliah Ekologi Tumbuhan Menggunakan Model Pembelajaran Inkuiri.

Konstruktivisme, 10 (2): 218-230

Kemampuan mahasiswa Tadris Biologi IAIN Palangka Raya dalam bertanya dan menjawab pertanyaan pada materi produktivitas tergolong sedang dengan skor 70 .

Kemampuan mahasiswa dalam mempertimbangkan sumber apakah dapat dipercaya atau tidak mendapat rengking terendah dari kelima kemampuan yang dinilai. Kemampuan mahasiswa Tadris Biologi IAIN Palangka Raya dalam mempertimbangkan sumber apakah dapat dipercaya atau tidak pada materi produktivitas tergolong sedang dengan skor 70 .

Keterampilan berpikir kritis mahasiswa didapatkan melalui proses pembelajaran dengan menggunakan model inkuiri. Pembelajaran dengan model inkuiri dalam tahapannya membantu mahasiswa untuk mengikuti langkah-langkah proses berpikir kritis. Langkah proses berpikir kritis Wolcott dan Lynch (1997) yaitu (1) Mengidentifikasi masalah, informasi yang relevan dan semua dugaan tentang masalah tersebut Ini termasuk kesadaran akan kemungkinan adanya lebih dari satu solusi, (2) Mengeksplorasi interpretasi dan mengidentifikasi hubungan yang ada. Ini termasuk mengenali bias/prasangka yang ada, menghubungkan alasan yang terkait dengan berbagai alternatif pandangan dan mengorganisir informasi yang ada sehingga menghasilkan data yang berarti, (3) Menentukan prioritas alternatif yang ada dan mengkomunikasikan kesimpulan. Ini termasuk proses menganalisis dengan cermat dalam mengembangkan panduan yang dipakai untuk menentukan faktor, dan mempertahankan solusi yang terpilih, (4) Mengintegrasikan, memonitor dan menyaring strategi untuk penanganan ulang masalah. Ini termasuk mengetahui pembatasan dari solusi yang terpilih dan mengembangkan sebuah proses berkelanjutan untuk membangkitkan dan menggunakan informasi baru.

\section{SIMPULAN}

Penelitian keterampilan berpikir kritis mahasiswa pada mata kuliah ekologi tumbuhan melalui pembelajaran inkuiri dapat meningkatkan keterampilan berpikir kritis mahasiswa. Rata-rata skor tertinggi pada indikator keterampilan berpikir kritis yang dinilai adalah memfokuskan pertanyaan dengan skor 73,64 yang terkategori sedang. Rata-rata skor terendah terdapat pada dua indikator, yaitu pada indikator bertanya dan menjawab pertanyaan dan indikator mempertimbangkan sumber apakah dapat dipercaya atau tidak. Kedua indikor tersebut sama-sama mendapatkan skor 70 dengan kriteria sedang. Rata-rata semua indikaor keterampilan berpikir kritis mahasiswa mendapat skor 71,27 dengan kriteria sedang. Pembelajaran inkuiri dapat meningkatkan keterampilan berpikir kritis mahasiswa dengan rata-rata kriteria sedang. 


\section{DAFTAR RUJUKAN}

Ariyati, E., 2015. Pengaruh Pembelajaran Inkuiri Terhadap Kemampuan Berpikir Kritis Mahasiswa. Prosiding Semirata 2015 bidang MIPA BKSPTN Barat Universitas Tanjungpura Pontianak Hal $519-527$.

Archambault, J. 2008. "The Effect of Developing Kinematics Concepts GraphicallyPrior to Introducing Algebraic Problem Solving Techniques". Action Research Reguared for the Master of Natural Science Degree with Concentration in Physics. Ari zona State University.

Ayatusa'adah. 2016. Pengembangan Lembar Kerja Siswa Konsep Daur Ulang Sampah Dan Pembelajarannya Menggunakan Model Pembelajaran Berdasarkan Masalah Tehadap Keterampilan Berpkir Tingkat Tinggi Di SMA. Edu Sains: Jurnal Pendidikan Sains \& Matematika, 4(1).

Chaeruman, Uwes. 2010. E-Learning dalam Pendidikan Jarak Jauh. Jakarta :Kemendiknas

Damayanti, D.S., Ngazizah, N., Eko S. K,. 2013. Pengembangan Lembar Kerja Siswa (LKS) Dengan Pendekatan Inkuiri Terbimbing Untuk Mengoptimalkan Kemampuan Berpikir Kritis Peserta Didik Pada Materi Listrik Dinamis SMA Negeri 3 Purworejo Kelas X Tahun Pelajaran 2012/2013. Jurnal Radiasi, 3(1).

Direktorat Jendral Pendidikan Tinggi. 2014. Buku Kurikulum Pendidikan Tinggi. Jakarta: Kementrian Pendidikan dan Kebudayaan.

Ennis, R. H. \& Weir, E. 1985. The Ennis Weir Critical Thinking Essay Test, Pacific Grove, CA : Midwest Publication, I.

Falahudin, I., Wigati, I., A. Pujiastuti. 2016. Pengaruh Model Pembelajaran Inkuiri Terbimbing Terhadap Kemampuan Berpikir Kritis Siswa Pada Pembelajaran Materi Pengelolaan Lingkungan Di SMP Negeri 2 Tanjung Lago, Kabupaten Banyuasin. Jurnal Bioilmi, 2(2), 92-101.

Fitriani, H., Ikhsan, M., 2017, Karaktristik Perangkat Pembelajaran Blended Community of Inquiry Yang Valid Untuk Melatih Keterampilan Berpikir Kritis Mahasiswa Calon Guru Biologi, Jurnal IImiah Pendidikan Biologi "Bioscientist" $5(2)$. 
Ayatusa'adah. 2018. Keterampilan Berpikir Kritis Mahasiswa Mata Kuliah Ekologi Tumbuhan Menggunakan Model Pembelajaran Inkuiri.

Konstruktivisme, 10 (2): 218-230

Ibrahim. (2007). Kecakapan Hidup: Keterampilan Berpikir Kritis. Surabaya: Universitas Negeri Surabaya.

Liliasari, 2009. Inovasi Pembelajaran Sains Menuju Profesionalisme Guru. Program Studi Pendidikan IPA Sekolah Pascasarjana UPI Bandung. (Online)

Paul, R. dan Elder, L. 2006. Critical Thinking (Concepts and Tools). The Foundation for Critical Thinking.

Syafitri, R., Asyhar, R., Asrial, 2016. Pengaruh Model Inquiry Training dan Berpikir Kritis Terhadap Kemampuan Berpikir IImiah Mahasiswa pada Mata Kuliah Kimia Dasar. Edu Sains, 5 (1).

Sagala, S. 2006. Konsep dan Makna Pembelajaran. Bandung: CV. Alfabeta

Sanjaya, W. 2006. Strategi Pembelajaran: Berorientasi Standar Proses Pendidikan. Jakarta: Kencana Prenada Media Grup.

Trianto. 2011. Mendesain Model Pembelajaran Inovatif-Progresif. Jakarta: Kencana.

Uno, G. E. 1990. Inquiry in the Classroom. BioScience Vol. 40, No. 11, pp. 841-843.

Oxford University Press on behalf of the American Institute of Biological Sciences.

Wolcott, SK \& Lynch, CL. 1997. Critical thinking in the accounting classroom: A reflective judgment developmental process perspective. Accounting Education: A Journal of Theory, Practice and Research, 2(1), 59-78.

Zubaidah, Siti. 2010. Berpikir Kritis: Kemampuan Berpikir Tingkat Tinggi yang Dapat Dikembangkan melalui Pembelajaran Sains. Makalah Disampaikan pada Seminar Nasional Sains 2010 dengan Tema "Optimalisasi Sains untuk Memberdayakan Manusia" di Pascasarjana Universitas Negeri Surabaya, 16 Januari 2010. 